\title{
Retrospective Mexican model of research managing: challenges and perspectives
}

\author{
Retrospectiva del modelo mexicano de gestión en la investigación: desafíos y \\ perspectivas
}

\author{
ESCOBEDO-MORATILLA, Abraham`† \& VÁZQUEZ-ELORZA, Ariel”** \\ 'CONACYT-Consortium for Research, Innovation and Development of the Drylands (CIIDZA), IPICYT, Camino a la Presa \\ San José 2055, Col. Lomas 4a Secc. CP. 78216, San Luis Potosí, SLP, Mexico \\ "CONACYT-Research Sistema Nacional de Investigadores. Economic-Agroindustrial Problems.
}

ID $1^{\text {st }}$ Author: Abraham, Escobedo-Moratilla / ORC ID: 0000-0003-4676-1625

ID $1^{\text {st }}$ Coauthor: Ariel, Vázquez-Elorza / ORC ID: 0000-0002-6710-8935

\begin{abstract}
In this article, we analyze a general context of the science and technology budget in Mexico and the description of this innovative model which has several challenges and opportunities for the development of the country. In the last decades, Mexican United States (Mexico) had been increased the expenditure in science and technology, however since 2016 due to several factors, this expenditure was modified, and the trend changed. One of the goals of the last administration was to begin the operation of new colaborative reforcement in Research Centers system and beginning of a new model denominates Research Consortiums of Consejo Nacional de Ciencia y Tecnología (CONACYT, for its acronym in Spanish), however, in recent years there have been changes and rearrangements of this system in order to adjust and reorient actions. Furthermore, It is also important to highlight that the current publication of the regulations of the National System of Researchers include incentives to take into account activities in favor of universal access to knowledge and the strengthening of scientific vocations.
\end{abstract}

Science and technology, innovation, S\&T investment research consortiums

\begin{abstract}
Resumen
En este artículo analizamos un contexto general del presupuesto de ciencia y tecnología en México y la descripción de este modelo innovador que presenta varios desafíos y oportunidades para el desarrollo del país. En las últimas décadas, en los Estados Unidos Mexicanos (México) se había incrementado el gasto en ciencia y tecnología, sin embargo, desde 2016 debido a varios factores, este gasto se modificó y la tendencia cambió. Una de las metas de la pasada administración fue iniciar la operación de un nuevo sistema de refuerzo colaborativo en los Centros de Investigación e inicio de un nuevo modelo que se denomina Consorcios de Investigación del Consejo Nacional de Ciencia y Tecnología (CONACYT), no obstante, en los últimos años se han producido cambios y reordenamientos de este sistema con el fin de ajustar y reorientar las acciones. Además, también es importante resaltar que la actual publicación de la normativa del Sistema Nacional de Investigadores incluye incentivos para tomar en cuenta actividades a favor del acceso universal al conocimiento y el fortalecimiento de las vocaciones científicas.
\end{abstract}

Ciencia y Tecnología; innovación, Inversión en ciencia y tecnología, Consorcios de investigación

Citation: ESCOBEDO-MORATILLA, Abraham \& VÁZQUEZ-ELORZA, Ariel. Retrospective Mexican model of research managing: challenges and perspectives. Journal of Social Researches. 2020. 6-18:16-24.

\footnotetext{
* Correspondence to Author (Email: avazquez@ ciatej.mx)

$\dagger$ Researcher contributing as first author.
} 


\section{Introduction}

Research in science, technology, and development is a fundamental tool for socioeconomic and regional growth for any country, boosting the knowledge economy, creating human capital, infrastructure and innovations that enhance the production function. According to World Bank (2020) the range related to investment in $\mathrm{I}+\mathrm{D}(\%$ of Gross Domestic Product in 2018) of 77 countries (which have the information) is between $4.25 \%$ and $0.1 \%$, in the case of Mexico is located in the 30th percentile with an investment of $0.31 \%$ compared with 71 countries - GDP. This situation shows that much remains to be done in the country to regard science and technology as a strategic sector compared to the rest of the world in advanced countries ${ }^{1}$.

Moreover, in 2018, Mexico participated in $0.95 \%$ of Trademark applications filed to register a trademark national Intellectual Property (IP) according to World Bank (2020b). In this segment stands out China, which made $61.85 \%$ of applications out of the $11,522,927$ filed internationally, followed by the United States (3.87\%) Japan (3.80\%). In this context, there is a need to increase investment in science, research, and technology to stop spending on imports of the world-generated, and relevant to the country's growth.

However, there is a national interest in increasing the levels of development in innovations, science and technology reflected in the documents that govern national planning in the sector. Currently the Mexican Government seeks to promote the National Innovation System, as set out in the National Development Plan (NDP) of Presidencia de la República de México 2019-2024 (2020, pág 151) "people will be provided with tools and skills that promote creative solutions to problems and drive technology research and development; instruments will also be developed to ensure effective protection of industrial and intellectual property".

\footnotetext{
1 When we analyzed research spending (1996-2016), among 77 countries that have the information World Bank (2020), by generating a cluster using the Ward method, we recognize that Mexico is in equal investment conditions together with countries, such as: Argentina, Latvia, Bulgaria, Romania, Cuba and Poland.

ECORFAN ${ }^{\circledR}$ All rights reserved.
}

It is also set out in Objective 3.3 of the NDP "To promote innovation, competition, integration into value chains and the generation of greater added value in all productive sectors under a sustainability approach... noting in paragraph 3.3.2 "Encouraging the development and adoption of new technologies in the production sectors and building capacities to take advantage of them, linking research with industry and users and promoting production methods sustainable [...]" Presidencia de la República de México 2019-2024 (2020, pág 157).

From an institutionalist approach, in Mexico, the Science and Technology (S\&T) are contemplated in 3 legal instruments: The Political Constitution of the Mexican United States, the Law of S\&T and the Organic Law of the Mexican Ministry of S\&T (CONACYT, for its acronym in Spanish). In the first place, the development for research, $S \& T$ is guaranteed by the fraction V of the article 3rd of the Political Constitution of the Mexican United States establishing that the State "[...] will support scientific and technological research, as wells as the strengthening and diffusion of our culture [...]" (Constitución Política de Los Estados Unidos Mexicanos, 2016).

In addition, the article 1 st of the S\&T Law has as a primary goal "[...] to regulate the Federal Government support which is obligated to give to boost, strengthen, develop and consolidate the scientific research, the technological development and the innovation in all the country [...]” (H. Congreso de la Unión, 2015).

In order to perform the mentioned constitutional command, the Mexican Ministry of S\&T which is a no sectorized, decentralized institution of the State, with legal personality and own assets, reasons why it has technical, operative and administrative autonomy. 
Moreover, the Organic Law of CONACYT stablishes in the article 2nd that "[...] the objective is being the advisory entity of the Federal Government and specialized in articulation the public politics as well as promote the development of the scientific and technological research, innovation, and the technological modernization of the country [...]" (H. Congreso de la Unión, 2014). In this context, the Federal Public Administration has obtained as result the conformation of the Public Research Centers (CPI's, for its acronym in Spanish) of CONACYT (CONACYT, 2017).

The article $47^{\text {th }}$ chapter IX of the Law of S\&T recognizes the existence of the CPI' of CONACYT " $[. .$.$] will be considered as Public$ Research Centers, the parastatal entities of the Public Federal Administration which according to it legal instrument of creation had as aim objective to perform scientific and technological research activities; that effectively perform such activities; and that they be recognized as such by resolution of the holders of CONACYT [...]" (H. Congreso de la Unión, 2015).

Detailing this point, the CPI's of CONACYT system are a network which was created by the Mexican Government and are sectorized inside the CONACYT $(\mathrm{H}$. Congreso de la Unión, 2014). These centers perform scientific and technological research with high specialization in different fields of science including exact and natural sciences, social sciences, and humanities, as well as engineering and technologies being one of the primary goals the training of human resources $(\mathrm{H}$. Congreso de la Unión, 2017).

Currently, in Mexico there exist 26 CPI's, of CONACYT system and one International Associated Organism and are distributed in 28 states and 61 cities; only two states, Colima and Morelos, do not have CPI's yet. Some centers have branches in several cities in order to cover most of the territory. These CPI's and their branches have about 20 years of experience as a formal instrument of the Mexican Government and they have the compromise of the scientific and technological advance of the country (CONACYT, 2017; $\mathrm{H}$. Congreso de la Unión, 2017).
The research centers of CONACYT system were founded since 1971 and the last one in the year 2000; on the 1970's decade other Institutions, such the Universidad Nacional Autónoma de México (UNAM), the Instituto Politécnico Nacional (IPN), the Colegio de México, the Universidad Autónoma Metropolitana and others, helped to establish the first 16 CPI's and at that moment the Education Ministry was responsible for managing all these institutions (CONACT, 2017). Nevertheless, from a legal perspective CPI's have different characteristics from those of the Public Universities and Institutions because according to the S\&T Law, which was approved in 2002, the CPI's are not autonomous from the Government (H. Congreso de la Unión, 2015). In Figure $\mathbf{1}$ is shown the chronology of foundation of the Mexican CPI's of CONACYT system; the last one was established in 2001.

\begin{tabular}{|c|c|c|c|}
\hline 1970 's & 1980's & 1990's & 2001 \\
\hline $\mathbb{1}$ trecan & cengugoo & 대고 & $\frac{W^{4}}{I P I C Y T}$ \\
\hline 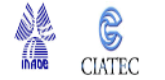 & $\int_{\text {CIMAT }}$ & (8) & \\
\hline $\mathbb{Z}_{\text {CICESE }}$ & (110 & (iman) & \\
\hline 17 & Im & F) & \\
\hline asoss & 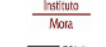 & & \\
\hline (2) 6 & CAnter & & \\
\hline $\begin{array}{c}\text { CIDE } \\
\text { calite } \\
0\end{array}$ & CDESI & & \\
\hline 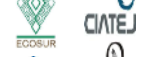 & & & \\
\hline (1) & & & \\
\hline 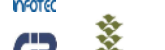 & & & \\
\hline (I) CICY & & & \\
\hline
\end{tabular}

Figure 1 Chronology of foundation of CPI's of CONACYT by decades. Since 2002, has not been established any other Center

Source: CONACYT (2017)

\section{Method}

In order to provide an economic outlook of Mexican S\&T of twelve last years (two presidential periods), the investment in S\&T were consulted in official legal documents of the national parliament as well as official databases of the Federal Government and from CONACYT in the period 2006-2018. Additionally, the budget of S\&T of the OECD countries was extracted from the same databases and compared by the elaboration of graphics in Microsoft Excel Professional Plus 2016. 
For graphics of the investment in S\&T were divided in two periods of six years, assuming that in each presidential period (January 2007-December 2012 and January 2013-December-2018) legal and politic factors contribute to these values; the total amount of the investment in millions of dollars was considered as Mexico Base $=100$ 2Q Dec, 2010. For graphics of $\%$ PIB and researchers for every 100,000 people in the workforce of OECD countries, it was included 1995, 2000 and 2005 data to clarify the trends.

Additionally, the mean strategies of S\&T managing and the total investment of last two years were described in detail to give context to the discussion. The project was divided by three stages: 1) collection of data, 2) analysis of the data, and 3) interpretation and discussion of the data. Due to the descriptive nature of the analysis, no statistical tests were required.

This research seeks to contribute to replicate the analysis at the state level to establish the bases that identify government actions to improve the living conditions of society; and with this, put into practice knowledge about the perspective of social and solidarity development.

\section{Results}

After the analysis of data, it was found that Federal Government fund the operating costs of the CPI's as basic services, wages and salaries of the personnel and some of the research projects; in this sense the total operation amount in 2018 was \$5,788 million pesos (SHCP, 2018b) approximately US\$304.6 million. Until the year 2017 , this 26 centers had 6,815 persons working inside divided in 70\% specialized personnel, $21 \%$ administrative personnel and 9\% middle and upper management personnel (SHCP, 2018). All together the CPI's of CONACYT system in that year offered 150 graduate programs including Master and Doctorate degrees. One issue is that the CPI's managed about \$2,264 million pesos (US\$ 119.5 million) as the total amount from private sector linking projects, while Public Universities managed $\$ 1,795$ million pesos (US\$ 94.47 million) in the 2014-2018 period, indicating a more powerful linkage system.
A way to look for incorporation of qualified researchers was the CONACYT Professorship Program (CONACYT, 2014). This program gave the opportunity to create new workplaces for young researchers in universities, academic institutions and CPI's improving the situation of a limited quantity of new researchers with work positions in the last decades. This program started in 2014 and it has incorporated 1508 researchers until 2018 (CONACYT, 2018a).

The Professorship program consists of a call in which the guidelines establish that each institution who wants a researcher needs to present a proposal explaining the project and the objectives of the work position; the researchers that want to be considered as candidates for these projects need to be registered in a list $(4,119$ registered until 2018), in order to be summoned by the interested institutions (CONACYT 2014).

After that, the institution selects three candidates and after a previous peer-review, CONACYT determines which candidate wins the workplace. The work positions are definitive and are paid by Federal budget until the retirement of the researchers or the suspension of the workplace due to the breach of objectives declared in the proposed project. The program establishes that young researchers access all the rights of a researcher of the receptor institution. However, the projects have a duration of ten years and at the end of the period, the project could be renewed or end, situation in which the researcher will be relocated in another project in the same institution or other (CONACYT, 2014).

Approximately, $85 \%$ of the projects and workplaces of the CONACYT Professorship Program have been approved for the states outside from the capital city and the three type of most benefited institutions have been: the Public Universities, CPI's from CONACYT System and Federal Institutions of Education (CONACYT, 2018a). 
Figure 2 shows the Federal expenditure on $\mathrm{S} \& \mathrm{~T}$ by socioeconomic objective, being in $2018, \$ 68,357$ million pesos in real terms (US\$ 3,607.19 million US - exchange rate one Dollar - 19 pesos); the sectors related to this spending are: the central, the parastatal, land exploration and exploitation, environment, space exploration and exploitation, transport, telecommunication and other infrastructures, energy, production and industrial technology, health, farming, culture, recreation, religion and mass media, systems, structures, political and social processes, general advance of knowledge and, defense (Presidencia de la República de México, 2018a). It also shows that in 2014 the largest amount of federal resources in the country for S\&T was allocated compared to the last two six-year periods.

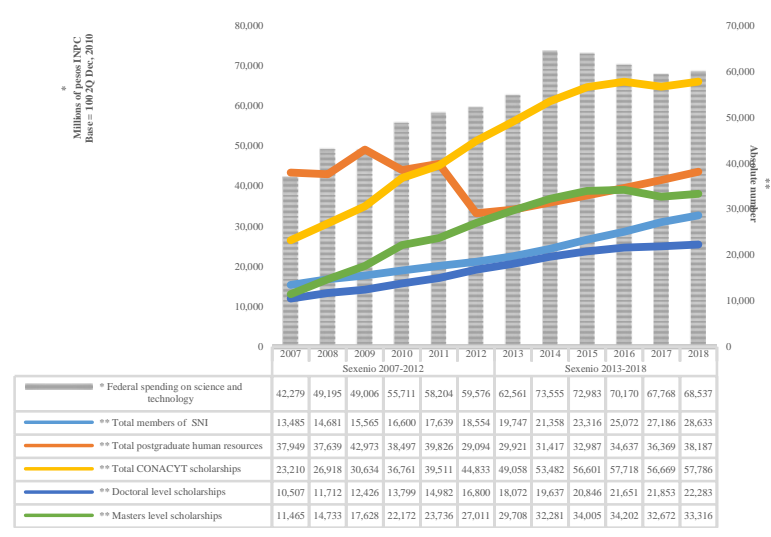

Figure 2 Trends in expenditure for Science and Technology, and indicators for the sector

Source: Presidencia de la República de México (2018a)

The Table 1 shows the expenditures for science and technology within the central and parastatal public administration in Mexico during the period 2006 and 2018, making a comparison of pesos to current and real prices to identify differences. To identify the level of change on the budget allocated to research in the country, we present below a comparison of current prices and constant prices. With this last indicator it is possible to compare growth, removing inflation.
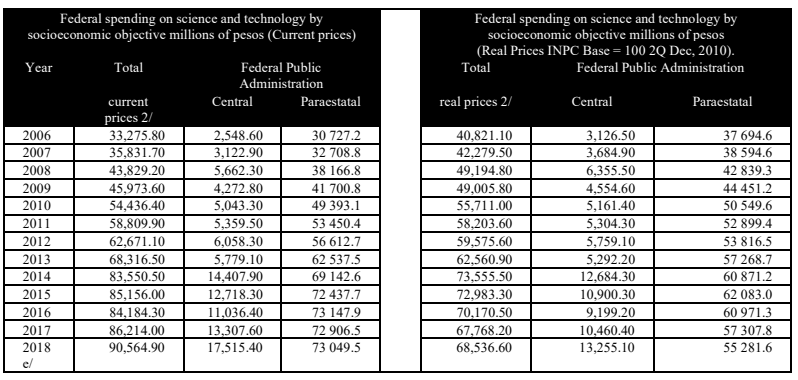

Table 1 Expenditures for science and technology within the central and parastatal public administration in Mexico during the period $2006-2018$

Source: Presidencia de la República de México (2018b)

ISSN: 2414-4835

ECORFAN ${ }^{\circledR}$ All rights reserved.
Figure 3 A) shows a reduction in scientific and technological development in recent years. When Mexico is compared with the Organization for Economic Co-operation and Development (OECD) countries, it is shown that spending as a percentage of the Gross Domestic Product (GDP, Base $2008=100$ ) represented $0.25 \%$ in the country, much lower than Germany, which invested $0.89 \%$ (Presidencia de la República de México, 2018a). The low levels of the country's budget allocation to science and research present some important effects that should be noted. Namely, the personnel dedicated to scientific and technological activities assigned to dependencies and entities of the Federal Government presented a Rate of Average Annual Growth (TCMA) in $-0.26 \%$ during the period 2006-2018 (Presidencia de la República de México, 2018a). However, there is also good news given that the number of fulltime equivalent researchers has grown with a TCMA of $4.93 \%$ during $1995-2016$ and of $10.08 \%$ in the members of the National Research System (Presidencia de la República de México, 2018a).

On the other hand, Mexico is located at the lowest level among the OECD countries with respect to the Researchers for every 10,000 people of the workforce as depicted in Figure 3 B) (Presidencia de la República de México, 2018a).

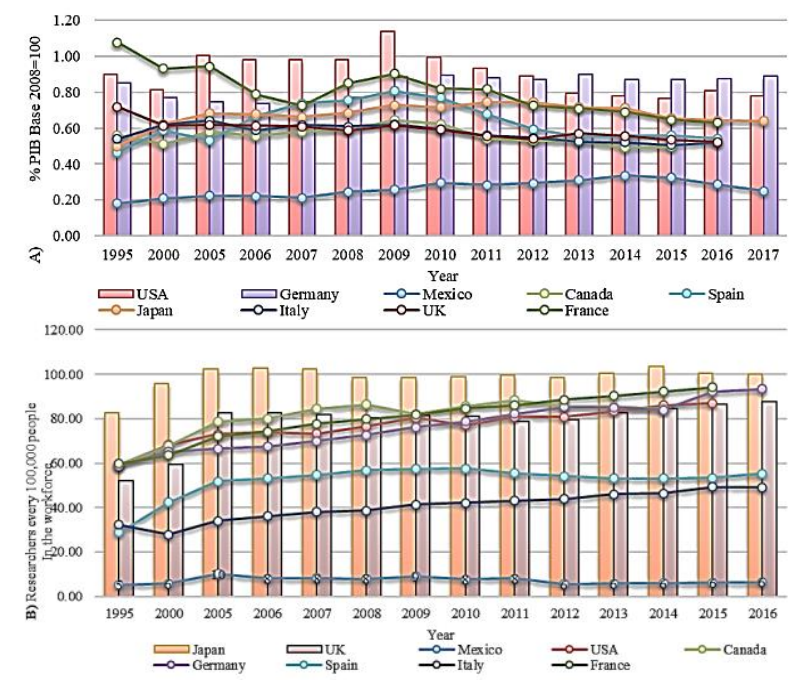

Figure 3 Comparison of indicators of the expenditure of Science and Technology since 1995 in OECD countries. A) Public budgetary allocation for scientific research and experimental development. B) Researchers for every 100,000 people in the workforce

Source: Presidencia de la República de México, (2018a) 
Although, the CPI's with all their branches in diverse regions in the country cover 30 from 32 states, it is considered by CONACYT that there is a lack of regional requirements in S\&T. For this reason, in the last Presidential period (2012-2018) the Direction of CONACYT proposed several public politics, like the creation of more CPI's, however, the economic conditions and financial restrictions in the Federal Government generated the emergence of another figure: CONACYT Consortiums. These Consortiums do not have legal personality yet, they consist in the alliance of two or more CPI's and since 2017 this model was promoted with the primary goal of "...to apply the scientific and technological capabilities in order to solve the problems and generate innovations in favor of diverse social and economic sectors of the different regions of the country..." (CONACYT, 2017; 2018a). Another aim objective of these entities is to improve the scientific and technological apparatus of Mexico because two or more CPI's which are integrated as Consortium can take advantage of the infrastructure and the human resources of them (CONACYT, 2018a).

Currently, there are at least 22 installed Consortia and there are other six in process of design or installation. Table 2 indicates the complete list of CONACYT Consortiums are already installed or operating over November 2018 and the economic sector they belong (CONACYT, 2017; 2018a).

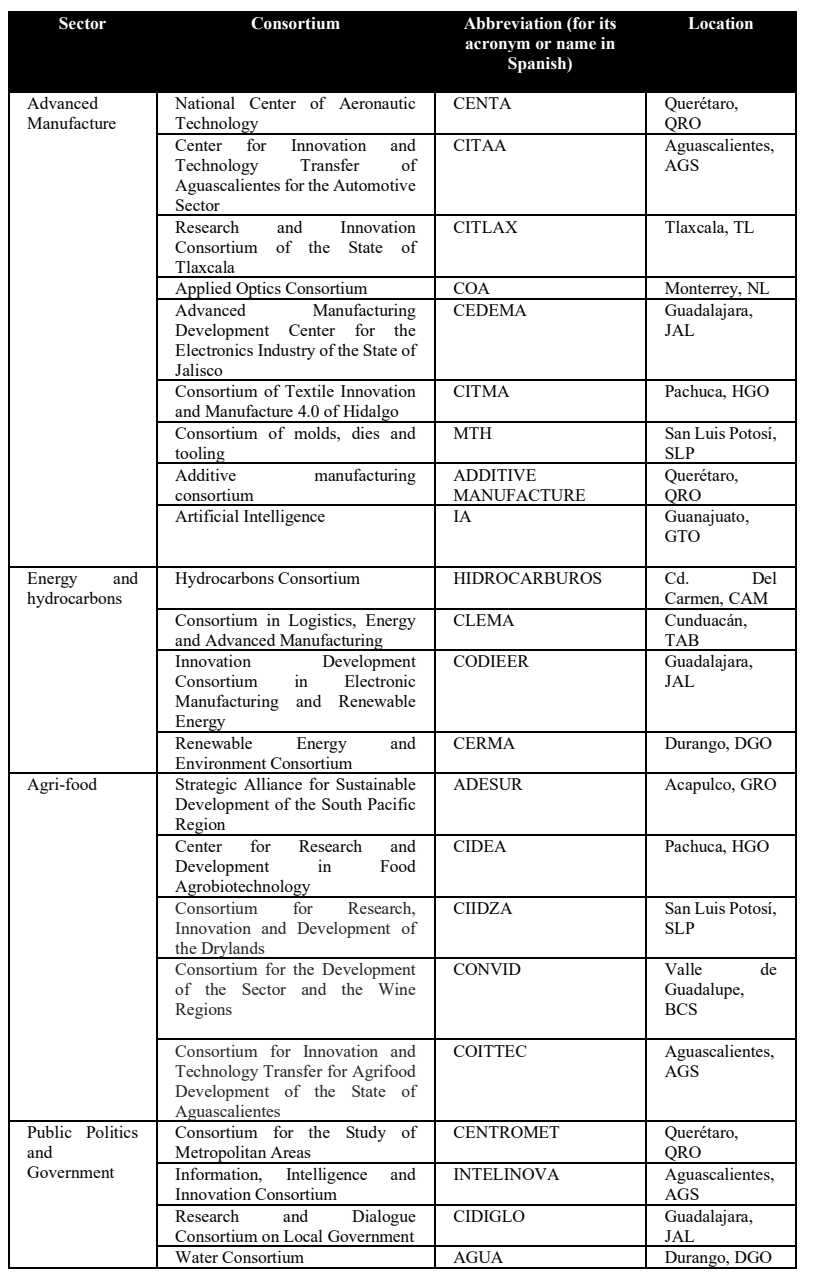

Table 2 CONACYT Consortia installed or in operation until September 2018

Source: CONACYT $(2017 ; 2020)$

In Figure 4, a map showing the localization of the current CONACYT Consortiums is depicted, showing a distribution along the entire country and decentralizing the "typical" area of action of the government facilities. However, to date, there have been important transformations, changes and redimensioning in the number of Consortiums generated in the country.



Figure 4 Localization of current 22 installed CONACYT Consortiums

Source: Consejo Nacional de Ciencia y Tecnología (CONACYT, 2014) 
Since 2017, CONACYT focused the Professorship program in the reinforcement of Consortiums in order to give them the human resources to operate. In this aspect, Figure 5 shows the distribution of the 156 young researchers that the Professorship Program has provided to 15 Consortiums in 10 States and being part of 55 projects proposed by these Consortiums (CONACYT 2017; 2018a).

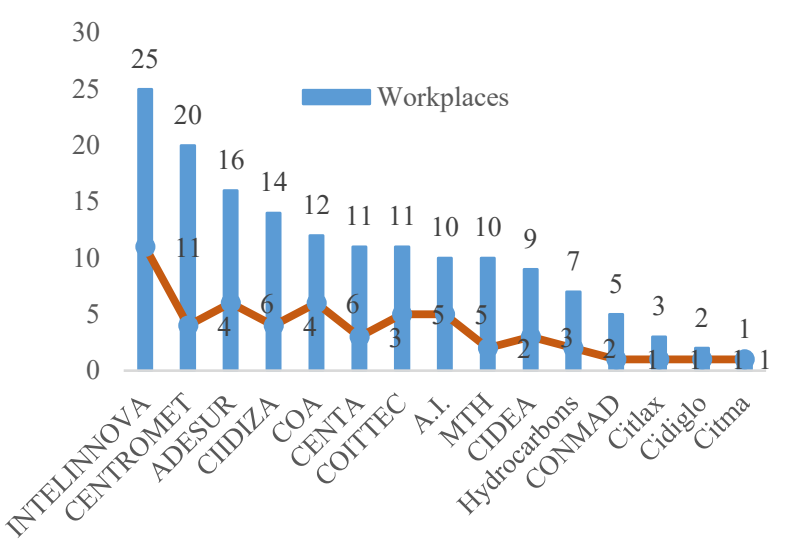

Figure 5 Distribution of workplaces of the CONACYT Professorship program in Consortiums and projects Source: Consejo Nacional de Ciencia y Tecnología (CONACYT, 2014)

Currently, the Mexican government will continue to strengthen policy and management in science and research given the proposed allocation of resources to the CPI's system of entities in the order of 25.6 BP (of which 15.4 $\mathrm{BP}$ corresponds to direct expenditure and 10.2 to subsidies), as set out in the 2019-2024 National Development Plan proposal. To be sure, I+D management represents a social challenge for national governments because the results are reflected in the economic impacts and increased domestic production function by including more technologies and investment. On the other hand, contributions and the transfer of knowledge in society and industry will enhance the creation of jobs and productive expansion dynamics. It is important to show that from the institutional point of view, CONACYT strengthens its commitment to Science and Technology by incorporating into the new regulations for the National System of Researchers (SNI, for its acronym in Spanish) the concept of generalized research for both the sciences and the humanities (CONACYT, 2020b).
The concept of universal access to knowledge and its benefits is incorporated in accordance with the provisions of article 3rd section $\mathrm{V}$ of the Constitution. Now it is the obligation of the SNI to evaluate universal access to knowledge and the strengthening of vocations. Likewise, it is contemplated to bring scientific and humanistic knowledge closer to the citizenry, as well as to promote its benefits to the public, social sector and to the citizenry. This new reality will generate tangible and intangible incentives for science and research to multiply and to really be useful to society in the country.

\section{Discussion and conclusions}

Undoubtedly, the growth in human capital and a reduction in personnel dedicated to research, S\&T ascribed to federal agencies will generate an oversupply in the research market and, a pressure that will result in an emigration of the researchers towards the exterior, greater competition between salaries and reduction of wages in response to a higher supply than demand in the sector; coupled with underutilization and inefficiency in human and social capital resources generated over the years and translated into tangible and intangible for S\&T. As mentioned above, in order to counter this situation, CONACYT implemented since 2014 a National Program called the Professorship program, with the purpose of including highly specialized human capital in national research, hired by the dependency under high standards of evaluation.

The year 2014 was characterized by reaching the greatest resources for science and research. According to information from the CONACYT from that time to date, approximately more than 2.1 billion pesos (US\$ 0.11 billion) have been invested in the Consortiums, adding Mixed Funds and Institutional Funds for Regional Development for Scientific, Technological and Innovation Development. It is important to highlight that the strategic sectors that have been oriented, up to this moment, are agri-food with 5 Consortia, advanced manufacturing with 9 ones, public politics and Government with 4 ones, and energy and hydrocarbons with other 4 (CONACYT, 2018a). 
During 2018, the Federal Government distributed $\$ 15,998.4$ million pesos (real prices INPC Base $=100$ 2Q Dec 2010 - US\$ 842.0 million -, which represented an amount of $\$ 21,140.4$ million pesos at current prices) for scientific research projects, technological development and innovation supported by mixed, sectoral funds and institutional fund to: the National System of Researchers, the scholarship program, postgraduate strengthening program, international scientific and technical cooperation, the training and updating courses of human resources, scientific and technological publications, and administration and planning (Presidencia de la República de México, 2018a).

However, the resources that were oriented to research have been decreasing in the last 4 years; For example, in 2015, \$21,520 million pesos (US\$ 1,132.63 million) were allocated, which, compared to the present date, amounted a reduction of 5,522 million pesos (US\$ 290.63 million) in real terms to research (Presidencia de la República de México, 2018a). In December $1^{\text {st }}$, 2018, a new Director of CONACYT was appointed, since a new Presidential period began (2018-2024). It is expected that the majority of the grants for applied science and development of technology stay current, however, it is not clear at this moment. Some declarations of the current Mexican Government suggest that basic science will be the mean objective of CONACYT as well as fighting against corruption of the sector (CONACYT, 2018), but it is unknown how will be distributed the budget of S\&T in the next 6 years.

As mentioned above Mexico have one of the lowest indicators of the expenditure of S\&T in comparison with OECD countries and the trend of the last six years is a decrease; in this sense, the CONACYT Consortia and other actions are expected to improve the situation of S\&T in the country, in order to trigger better conditions of economic development in the next years.
Finally, the current publication of the new Regulation of the SNI opens the door to increase the transfer and social value of science and research in Mexico. It includes intangible incentives that would promote the creation of social innovations regardless of economic resources. Even the positive externalities in the benefits of science and technology in society could be greater than the tangible economic investments

\section{Acknowledgments}

Authors thanks to CONACYT Associate Directors of the period 2012-2018 for kindly provided some of the graphs and data presented in the article. AEM and AVE are benefited from the FORDECYT grant, project no. 2018/296354 and 2018/296353, respectively.

\section{References}

Consejo Nacional de Ciencia y Tecnología (CONACYT). (2014). Cátedras Conacyt. ¿Qué Son Las Cátedras Conacyt? https://www.conacyt.gob.mx/index.php/elconacyt/desarrollo-cientifico/catedrasconacyt

Consejo Nacional de Ciencia y Tecnología (CONACYT). (2017a). Informe general del estado de la ciencia, tecnologia e-innovacion. Informe general. https://www.siicyt.gob.mx/index.php/transpare ncia/informes-conacyt/informe-general-delestado-de-la-ciencia-tecnologia-einnovacion/informe-general-2017/4813informe-general-2017/file

Consejo Nacional de Ciencia y Tecnología (CONACYT). (2017b). Reorganización del Sistema de Centros Públicos en Investigación del Consejo Nacional de Ciencia y Tecnología. Reorganizan El Sistema de Centros Públicos de Investigación de CONACYT. https://centrosconacyt.mx/objeto/reorganizacion -de-cpi/

Consejo Nacional de Ciencia y Tecnología (CONACYT). (2018a). ler Encuentro de Gerentes de Consorcios CONACYT. https://www.notimx.mx/2018/09/se-realiza-elprimer-encuentro-de.html 
Consejo Nacional de Ciencia y Tecnología (CONACYT). (2018b). Más apoyo a la ciencia de frontera: María Elena Álvarez-Buylla. http://conacytprensa.mx/index.php/sociedad/pol itica-cientifica/24358-apoyo-ciencia-fronteraelena-alvarez-buylla.

Consejo Nacional de Ciencia y Tecnología (CONACYT). (2020a). Consorcios CONACYT. https://www.conacyt.gob.mx/index.php/consorc ios

Consejo Nacional de Ciencia y Tecnología (CONACYT). (2020b). Reglamento del Sistema Nacional de Investigadores (SNI). https://www.conacyt.gob.mx/index.php/elconacyt/sistema-nacional-deinvestigadores/marco-legal/reglamentosni/20142-reglamento-sni/file

H. Congreso de la Unión. (2014). Ley Orgánica del Consejo Nacional de Ciencia y Tecnología. http://www.diputados.gob.mx/LeyesBiblio/pdf/ 243.pdf

H. Congreso de la Unión. (2015). Ley de Ciencia y Tecnología. Ley de Ciencia y Tecnología. Última Reforma Publicada DOF 08-12-2015. http://www.diputados.gob.mx/LeyesBiblio/pdf/ 242_081215.pdf

Constitución Política de los Estados Unidos Mexicanos, Diario Oficial de la federación 1 (2016). https://doi.org/10.1017/CBO9781107415324.00 4

H. Congreso de la Unión. (2017). Manual de Organización del Consejo Nacional de Ciencia $y$ Tecnología. http://www.diputados.gob.mx/LeyesBiblio/regl a/n285.pdf

Presidencia de la República de México. (2018a). 6to Informe de Gobierno.

Presidencia de la República de México. (2018b). Sexto Informe de Gobierno. Sexto Informe de Gobierno.

https://datos.gob.mx/busca/dataset/sextoinforme-de-gobierno

Presidencia de la República de México. (2020). Plan Nacional de Desarrollo (PND) 2019-2024. https://www.ppef.hacienda.gob.mx/work/model s/PPEF2020/docs/38/r38_redg.pdf
Secretaría de Hacienda y Crédito Público (SHCP). (2018a). Analítico de Plazas y Remuneraciones.

https://www.pef.hacienda.gob.mx/es/PEF2018/t omoIX-IV

Secretaría de Hacienda y Crédito Público (SHCP). (2018b). Presupuesto de Egresos de la Federación 2018. https://www.pef.hacienda.gob.mx/work/models /PEF2018/docs/38/r38_reurgfpp.pdf

World Bank. (2020a). Gasto en investigación y desarrollo (\% del PIB). Instituto de Estadística de La Organización de Las Naciones Unidas Para La Educación, La Ciencia y La Cultura ( UNESCO

https://datos.bancomundial.org/indicador/GB.X PD.RSDV.GD.ZS

World Bank. (2020b). World Intellectual Property Organization (WIPO). The International Bureau of WIPO. Statistics Database Intellectual Property. https://databank.worldbank.org/reports.aspx?so urce $=2 \&$ series $=$ IP.TMK.RSCT\#

ESCOBEDO-MORATILLA, Abraham \& VÁZQUEZELORZA, Ariel. Retrospective Mexican model of research managing: challenges and perspectives. Journal of Social Researches. 2020 